\title{
Effect of the infection with the nematode Haemonchus contortus (Strongylida: Trichostrongylidae) on the haematological, biochemical, clinical and reproductive traits in rams
}

\begin{tabular}{|c|c|}
\hline $\begin{array}{l}\text { Authors: } \\
\text { Mariem Roua } \\
\text { Mohamed Gh } \\
\text { Mohamed R. } \\
\text { Imen Ben Sale } \\
\text { Hafidh Akkari } \\
\text { Narjess Lasso } \\
\text { Mourad Rekik }\end{array}$ & $\begin{array}{l}\mathrm{bi}^{1} \\
\mathrm{arbi}^{1} \\
\mathrm{jeibi}^{2}\end{array}$ \\
\hline \multicolumn{2}{|c|}{ 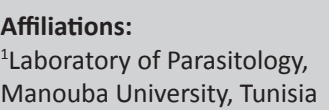 } \\
\hline \multicolumn{2}{|c|}{$\begin{array}{l}{ }^{2} \text { Department of Animal } \\
\text { Production, Service of Animal } \\
\text { Science, Manouba University, } \\
\text { Tunisia }\end{array}$} \\
\hline \multicolumn{2}{|c|}{$\begin{array}{l}{ }^{3} \text { Department of Animal and } \\
\text { Forage, National Institute of } \\
\text { Agronomic Research of } \\
\text { Tunisia, Tunisia }\end{array}$} \\
\hline \multicolumn{2}{|c|}{$\begin{array}{l}{ }^{4} \text { International Center for } \\
\text { Agricultural Research in the } \\
\text { Dry Areas, Amman, Jordan }\end{array}$} \\
\hline \multicolumn{2}{|c|}{$\begin{array}{l}\text { Research Project no.: } \\
\text { LR02AGR03 }\end{array}$} \\
\hline \multicolumn{2}{|c|}{$\begin{array}{l}\text { Corresponding author: } \\
\text { Mohamed Rjeibi, } \\
\text { medridharjeibi@yahoo.fr }\end{array}$} \\
\hline $\begin{array}{l}\text { Dates: } \\
\text { Received: } 04 \\
\text { Accepted: } 12 \\
\text { Published: } 30\end{array}$ & $\begin{array}{l}\text { lec. } 2015 \\
\text { May } 2016 \\
\text { Aug. } 2016\end{array}$ \\
\hline \multicolumn{2}{|c|}{ Read online: } \\
\hline 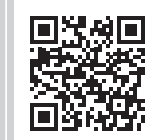 & $\begin{array}{l}\text { Scan this QR } \\
\text { code with your } \\
\text { smart phone or } \\
\text { mobile device } \\
\text { to read online. }\end{array}$ \\
\hline
\end{tabular}

This study aimed to investigate the effect of Haemonchus contortus infection on rams' haematological, biochemical and clinical parameters and reproductive performances. A total number of 12 Barbarine rams (control and infected) were included in the experiment. The infected group received $30000 \mathrm{H}$. contortus third-stage larvae orally. Each ram's ejaculate was immediately evaluated for volume, sperm cell concentration and mortality rate. At the end of the experiment (day 82 post-infection), which lasted 89 days, serial blood samples were collected in order to assess plasma testosterone and luteinising hormone (LH) concentrations. There was an effect of time, infection and their interaction on haematological parameters $(p<0.001)$. In infected rams, haematocrit, red blood cell count and haemoglobin started to decrease from 21 days post-infection. There was an effect of time and infection for albumin. For total protein, only infection had a statistically significant effect. For glucose, only time had a statistically significant effect. Concentrations were significantly lower in infected rams compared to control animals. A significant effect of infection and time on sperm concentrations and sperm mortality was observed. The effect of infection appears in time for sperm concentrations at days 69 and 76 post-infection. Sperm mortality rate was significantly higher in infected animals at day 46 post-infection when compared to control group $(p<0.05)$. Finally, plasma testosterone traits (average concentration, cumulated levels during the sampling period and pulse frequency) were depressed in infected rams when compared to control counterparts; none of these endocrine traits were affected for plasma LH.

\section{Introduction}

Thermo-period, photoperiod and nutrition are usually regarded as the main environmental factors affecting reproductive performance of livestock species under arid and semi-arid environments (Gonzalez-Bulnes et al. 2010). In small ruminants, the impact of disease on reproductive efficiency is not as well studied as in cattle and particularly when it is in relation to enzootic diseases such as gastrointestinal helminth infections. In Southern Mediterranean countries, small ruminants face important health problems with high prevalences of several diseases such as brucellosis, foot and mouth disease, border disease and several parasitic infections such as Toxoplasma gondii infection (Gharbi et al. 2013), fasciolosis (Akkari, Gharbi \& Darghouth 2011), lungworms and gastrointestinal helminths (Akkari, Gharbi \& Darghouth 2012).

In Tunisia, for example, control measures of gastrointestinal helminths are hampered by (1) a very important diversity of epidemiological features through a north-south axis going, respectively, from humid to Saharan climate (Darghouth, unpublished data), (2) the absence of standard control programmes against gastrointestinal helminths based on epidemiological data and (3) very high parasite infection indicators. Indeed, Akkari et al. (2012) showed that $45.5 \%$ of the parasite population were found in the abomasum, with the prevalence of Haemonchus contortus exceeding $35 \%$.

While the hematophagous nature of this common pathogenic parasite is well documented, there is little information on how essential functions such as reproduction may be affected when animals are infected with $H$. contortus. It is commonly assumed that, intuitively, parasite infection renders

How to cite this article: Rouatbi, M., Gharbi, M., Rjeibi, M.R., Ben Salem, I., Akkari, H., Lassoued, N. et al., 2016, 'Effect of the infection with the nematode Haemonchus contortus (Strongylida: Trichostrongylidae) on the haematological, biochemical, clinical and reproductive traits in rams', Onderstepoort Journal of Veterinary Research 83(1), a1129. http://dx.doi.org/10.4102/ojvr.v83i1.1129

Copyright: @ 2016 . The Authors. Licensee: AOSIS. This work is licensed under the Creative Commons Attribution License. 
the animals ill, hence affecting all functions. Nevertheless, chronically affected animals are commonly present in flocks kept for production and reproduction without any objective assessment of the shortfalls on their reproductive performance. This study therefore attempted to study the effects of a chronic infection with $H$. contortus on semen and associated endocrine traits of adult Barbarine rams.

\section{Materials and methods}

The trial was carried out during the transition phase between the breeding and the non-breeding seasons (from November to February). The work was performed in the governorate of Ben Arous, at the experimental station of Bourebiaà (National Institute of Agronomic Research of Tunisia [INRAT]; latitude $36^{\circ} 38 \mathrm{~N}$; longitude $10^{\circ} 07 \mathrm{E}$ ). The average annual rainfall (the mean of the last 30 years) was $350 \mathrm{~mm}$. Averages of the ambient temperature were $10.6{ }^{\circ} \mathrm{C}, 9.4{ }^{\circ} \mathrm{C}$ and $10.3^{\circ} \mathrm{C}$ during December, January and February, respectively. Ethical concerns were taken into account by adhering to local animal welfare regulations and practices and conformed to ethical guidelines for animal usage in research of the National School of Veterinary Medicine of Sidi Thabet (Tunisia) and the Association Tunisienne des Sciences des Animaux de Laboratoire (ATSAL/0116, Tunisia).

\section{Animals and management}

A total number of 12 healthy adult Barbarine rams accustomed to ejaculation in an artificial vagina, aged between 2.5 and 5 years (mean: 3.25 years), weighing between $46 \mathrm{~kg}$ and $71 \mathrm{~kg}$ (mean: $62 \mathrm{~kg}$ ) were included in the trial. The choice of the number of animals was motivated by the principle of reduction proposed by Russell and Burch (1959). They were divided into two homogenous groups (infected and control) which did not statistically differ in age and live weight. The rams were housed individually in cleaned experimental pens of $2 \mathrm{~m}^{2}(1 \mathrm{~m} \times 2 \mathrm{~m})$, and they were allowed an adaptation period of 18 days for the new housing and feeding conditions; they were fed ad libitum with hay and had continuous access to fresh water. Throughout the experiment, the animals were exposed to natural daylight.

\section{Parasitic infection and experimental treatments}

All the animals were initially drenched with albendazole (Dalben ${ }^{\circledR} 1.9$, CEVA laboratories, Tunis, Tunisia) $(7 \mathrm{mg} / \mathrm{kg})$ two times at an interval of three days. The animals were sampled for coprology with the flotation and Baermann (Bussiéras \& Chermette 1995; Euzéby 1981) techniques every week for three consecutive weeks. During the third week, all faecal samples were negative for both respiratory and gastrointestinal helminths. The rams belonging to the infected group received $30000 \mathrm{H}$. contortus third-stage larvae orally as described by Bordoloi, Jas and Ghosh (2012). Haemonchus contortus larvae were obtained from a donor ram infected with this parasite. This was considered as the starting point of the experiment which lasted for 89 days. Care was taken for control animals not to be in contact, directly or indirectly, with infected animals. For everyday care and for experimental interventions, workers and staff always started with control animals before moving to the infected ones.

\section{Parasitological, haematological, biochemical and clinical parameters}

On a weekly basis, throughout the experiment and for all animals, faecal egg counts (FEC) were qualitatively assessed to verify whether gastrointestinal parasite eggs were present or absent in the faeces. For positive rams, the quantification was done on day 30 and day 70 post-infection with McMaster technique (Raynaud 1970) consisting of two counting chambers. The formula that was used is FEC = number of eggs in the two compartments $\times 50$. EDTA blood samples were collected weekly from the rams. Plasma was recovered and stored at -20 ${ }^{\circ} \mathrm{C}$ until analysed. Haematological parameters: haematocrit $(\%)$, red blood cell count $\left(\times 10^{6} / \mathrm{mL}\right)$ and haemoglobin $(\mathrm{g} / \mathrm{dL})$ were estimated using an Auto Haematology analyser BC2800 Vet ${ }^{\circledR}$ (Shenzen Mindray Bio-Medical Electronics Co., Ltd, Hamburg, Germany). Plasma samples were also used to estimate biochemical indicators: albumin ( $\mathrm{g} / \mathrm{L})$, glucose $(\mathrm{mmol} / \mathrm{L})$ and total proteins $(\mathrm{g} / \mathrm{L})$ with a Random Access Clinical Autolyzer ${ }^{\circledR}$ (Dialab, Vienna, Austria). Heart rate (beats per minute), respiratory rate (breaths per minute) and rectal temperature $\left({ }^{\circ} \mathrm{C}\right)$ were measured weekly.

\section{Live weight and scrotal circumference}

Live weight and scrotal circumference were measured every 2 weeks. At each occasion, the rams were weighed twice before being fed in the morning. Scrotal circumference was assessed with a measuring tape $( \pm 1 \mathrm{~mm})$ at the greatest diameter along the scrotum with the ram in a standing position. No correction was made for scrotal skin thickness.

\section{Semen collection and evaluation}

Starting 25 days after infection with $H$. contortus larvae, the volume of ejaculate, sperm concentration and sperm mortality rate were measured at weekly intervals by collecting semen using an artificial vagina kept in a water bath at $35{ }^{\circ} \mathrm{C}$. During semen collection, animals were put individually in the presence of a teaser female that was previously induced into oestrus by inserting a progestagenimpregnated vaginal sponge for 10 days. Each ejaculate was recovered in glass tubes graduated to the nearest $0.1 \mathrm{~mL}$ allowing determination of the volume directly in the tube. Concentration of spermatozoids (number of spermatozoa/ $\mathrm{mL}$ ) was estimated after diluting semen in $9 \%$ sodium chloride using a spectrophotometer at $550 \mathrm{~nm}$ wave length (Accucell $^{\circledR}$, IMV, L'Aigle, France). Assessment of dead spermatozoa was undertaken utilising an eosin-nigrosin staining method described by Baril et al. (1993).

\section{Plasma testosterone and luteinising hormone concentrations}

Eighty-two days post-infection, serial blood samples were taken during six consecutive hours every $20 \mathrm{~min}$ from the 
jugular vein with heparinised vacutainer ${ }^{\circledR}$ tubes. Plasma was collected after being centrifuged ( $3000 \mathrm{~g}, 15 \mathrm{~min})$, then stored at $-20{ }^{\circ} \mathrm{C}$ until assayed. Plasma concentrations of testosterone and luteinising hormone (LH) were estimated using a monoclonal antibody, non-extraction radioimmunoassay method. Plasma testosterone and LH concentrations were determined in duplicate with Coat-A-Count ${ }^{\circledR}$ radioimmunoassay kits (Diagnostic Products Corporation, Los Angeles, USA), according to the manufacturer's instructions. For both testosterone and LH, all samples were, respectively, included in one single assay. Intra-assay variation coefficients were $2.51 \%$ and $10.89 \%$, respectively, for testosterone and LH concentrations. An increase greater than the mean of testosterone (or LH) in all samples taken in the 6-h period plus two standard deviations followed by a decrease was considered as a pulse (Diekman et al. 1991).

\section{Statistical analyses}

Results for haematocrit, red blood cell count, haemoglobin, albumin, total proteins, glucose, live weight, scrotal circumference, concentration, sperm mortality rate in the ejaculates and the ejaculates volume were analysed using factorial Analysis of variance (ANOVA) with two independent factors: infection with $H$. contortus and time. The analysis was performed using SPSS software for Windows version 18. These analyses allow testing the effect of treatment, time and their interaction. When treatment and time had a significant effect, further analyses were performed using repeatedmeasures analysis of variance with $\mathrm{XISTAT}^{\circledR}$, adware for Excel $^{\circledR}$ to depict when this effect appears over time. For individual profiles of testosterone and LH, areas delineated by measured concentrations were calculated using the trapezoid rule using GeoGebra ${ }^{\circledR}$ (version 4.0, International GeoGebra Institute, Linz, Australia). Data on the number of testosterone pulses frequency were converted to the square root of $n+0.5$ because some rams, particularly in the control group, had zero pulse frequencies (Dickson \& Sanford 2005). The comparison between groups of animals was undertaken using Student's $t$-test. The Pearson's correlation was used to assess the relationship between testosterone and LH plasma concentrations. The effect of infection was considered significant when the level of probability was 0.05 or less. Results are presented as means \pm S.E.M unless specified otherwise.

Threshold values used for haematological and biochemical parameters are shown in Table 1 (Blood \& Radostits 1989).

\section{Results \\ Parasitological infection}

Faecal samples of all animals were negative for gastrointestinal and lungworms immediately before infection. Three weeks after infection, infected rams started shedding $H$. contortus eggs while none of the control rams excreted eggs. This worm burden was maintained throughout the experiment (to day 89) and was weekly verified by qualitative coprology.
TABLE 1: Haematological and biochemical threshold values.

\begin{tabular}{lc}
\hline Parameter & Threshold value \\
\hline Haematological parameters & \\
Red blood cells $\left(10^{12} / \mathrm{L}\right)$ & $5.0-14.0$ \\
Haemoglobin $(\mathrm{g} / \mathrm{dL})$ & $9.0-15.5$ \\
Haematocrit $(\%)$ & $26.0-45.0$ \\
Biochemical parameters & \\
Albumin (g/L) & $24-30$ \\
Glucose (mmol/L) & $2.8-4.5$ \\
Total proteins (g/L) & $60-79$ \\
\hline
\end{tabular}

Source: Blood, D.C. \& Radostits, O.M., 1989, Veterinary medicine, Baillière Tindall, London

Infected rams excreted $H$. contortus eggs throughout the experiment but none of the control animals did. At days 30 and 70 post-infection, the faecal egg counts in the six infected animals reached an average of $6200 \mathrm{eggs} / \mathrm{g} \pm 664.24 \mathrm{eggs} / \mathrm{g}$ and $5000 \mathrm{eggs} / \mathrm{g} \pm 886.00 \mathrm{eggs} / \mathrm{g}$, respectively.

\section{Haematological parameters}

Factorial ANOVA with two independent factors showed a statistically significant effect of time, infection and the interaction infection*time on haematological parameters $(p<0.001)$. Repeated-measures ANOVA showed that the effect of time appears in infected group from day 47 postinfection. In fact, haematocrit, red blood cell count and haemoglobin decreased significantly in infected rams from $26.90 \% \pm 1.06 \%, 5.69 \pm 0.31 \times 10^{12} / \mathrm{L}$ and $6.83 \mathrm{~g} / \mathrm{dL} \pm 0.29 \mathrm{~g} / \mathrm{dL}$ at 47 days post-infection to $18.37 \% \pm 1.81 \%, 4.24 \pm 0.31$ $\times 10^{12} / \mathrm{L}$ and $4.25 \mathrm{~g} / \mathrm{dL} \pm 0.46 \mathrm{~g} / \mathrm{dL}$, respectively $(p<0.05)$ at 89 days after infection (Figure $1 \mathrm{a}-\mathrm{c}$ ); corresponding values in control animals remained roughly constant $(p>0.05)$. The effect of infection was different for the three parameters. In fact, differences between control and infected rams started to be statistically significant from day 47 post-infection for haematocrit and from day 29 post-infection till the end of the trial for red blood cells and haemoglobin.

\section{Biochemical and clinical parameters}

Factorial ANOVA with two independent factors showed a statistically significant effect of time $(p=0.044)$ and infection $(p=0.002)$ for albumin. For total proteins, only treatment had a statistically significant effect $(p=0.003)$. For glucose, only time had a statistically significant effect $(p<0.001)$. For albumin and total protein concentrations, further analyses of the effect of infection showed that these concentrations were significantly lower in infected rams compared to control animals $(p<0.05)$. This difference was observed at days 47,57 and 64 for albumin and at day 78 for total proteins $(p<0.05)$ (Figure $2 \mathrm{a}$ and $\mathrm{b}$ ). Regardless of the infection status, the concentration of glucose increased in time (Figure 2c). No significant treatment differences were found for heart rate, respiratory rate frequency and rectal temperature.

\section{Live weight and scrotal circumference}

Factorial ANOVA with two independent factors showed that there was not a statistically significant effect of infection, time and the interaction infection*time on live weight and scrotal 


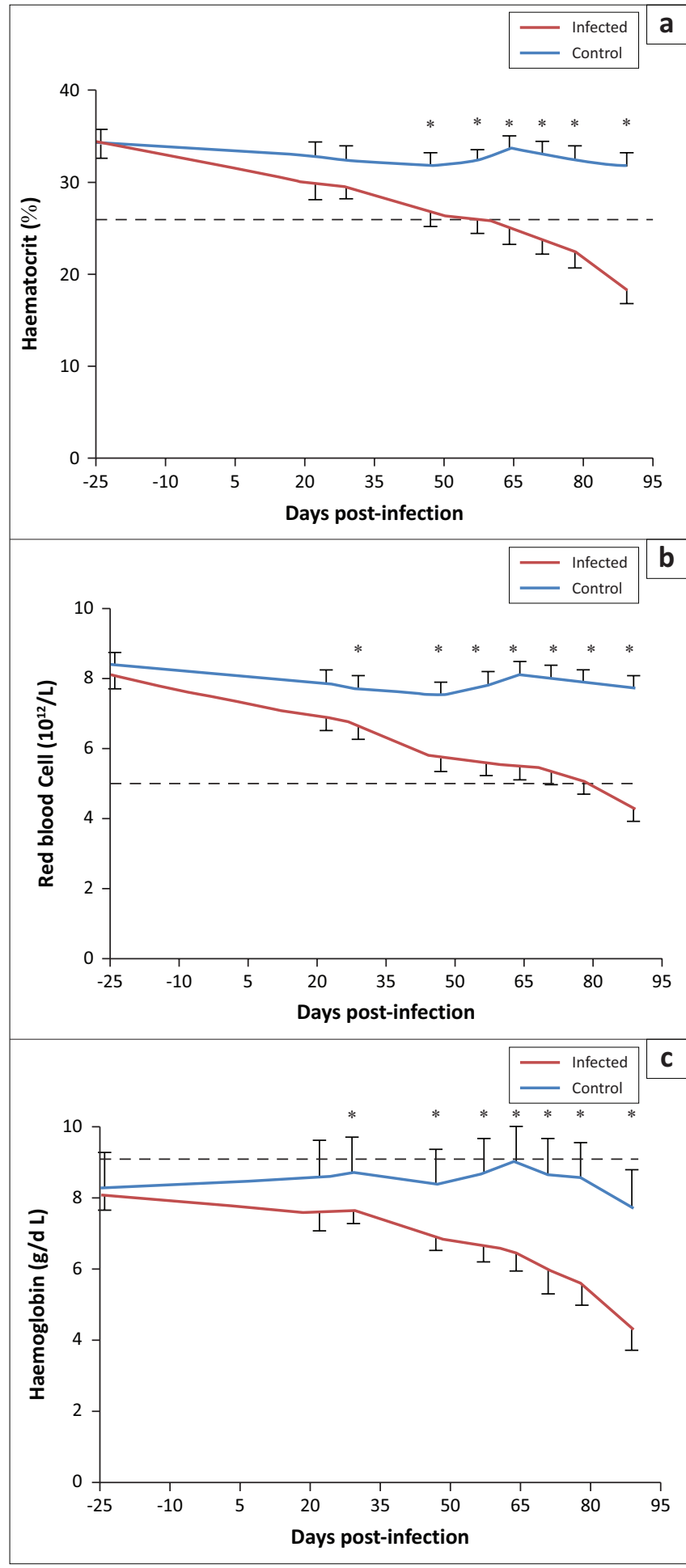

Dotted lines: threshold values.

*, differences between control and infected rams are significant at $p<0.05$.

FIGURE 1: Variation of (a) haematocrit, (b) red blood cell count and (c) haemoglobin in Haemonchus contortus infected and control rams.

circumference between infected and control animals $(p>0.05)$. Live weight averages were $61.75 \mathrm{~kg} \pm 3.51 \mathrm{~kg}$ and $56.63 \mathrm{~kg} \pm$ $4.59 \mathrm{~kg}$ at the beginning of the experiment and reached 65.58 $\mathrm{kg} \pm 3.67 \mathrm{~kg}$ and $61.40 \mathrm{~kg} \pm 2.26 \mathrm{~kg}$ at day 78 post-infection for control and infected rams, respectively. Scrotal circumference values amounted to $24.50 \mathrm{~cm} \pm 1.85 \mathrm{~cm}$ and $26.67 \mathrm{~cm} \pm 1.17 \mathrm{~cm}$ at day 22 post-infection to $24.58 \mathrm{~cm} \pm 1.34 \mathrm{~cm}$ and $25.17 \mathrm{~cm} \pm$ $1.73 \mathrm{~cm}$ at day 78 for control and infected animals, respectively.
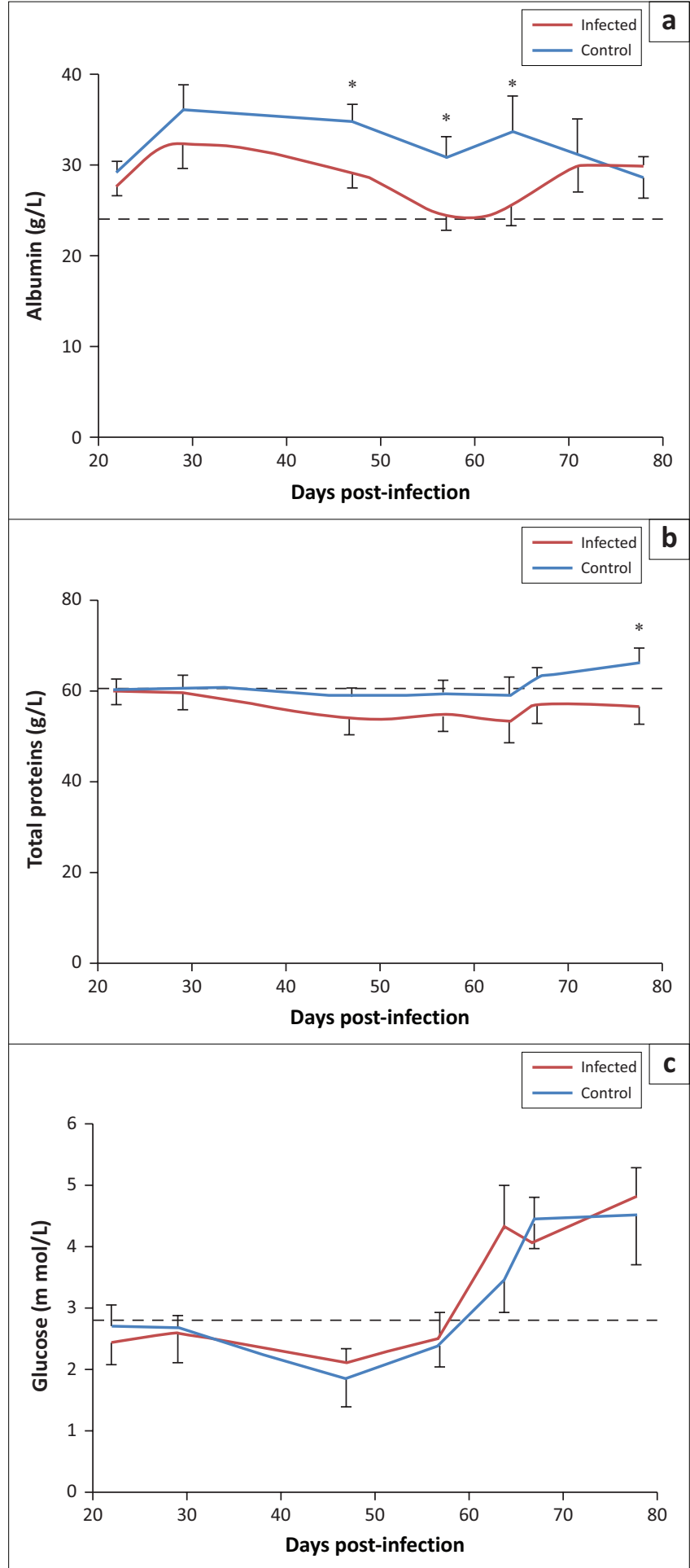

Dotted lines: threshold values.

*, differences between control and infected rams are significant at $p<0.05$.

FIGURE 2: Variation of (a) albumin, (b) total proteins and (c) glucose in Haemonchus contortus infected and control rams.

\section{Semen traits}

Factorial ANOVA with two independent factors showed a statistically significant effect of infection and time for sperm concentrations ( $p=0.016$ and $p=0.032$, respectively) and sperm mortality ( $p=0.001$ and $p=0.022$, respectively). The effect of infection appears in time for sperm concentrations at days 69 and 76 post-infection (Figure 3a). 

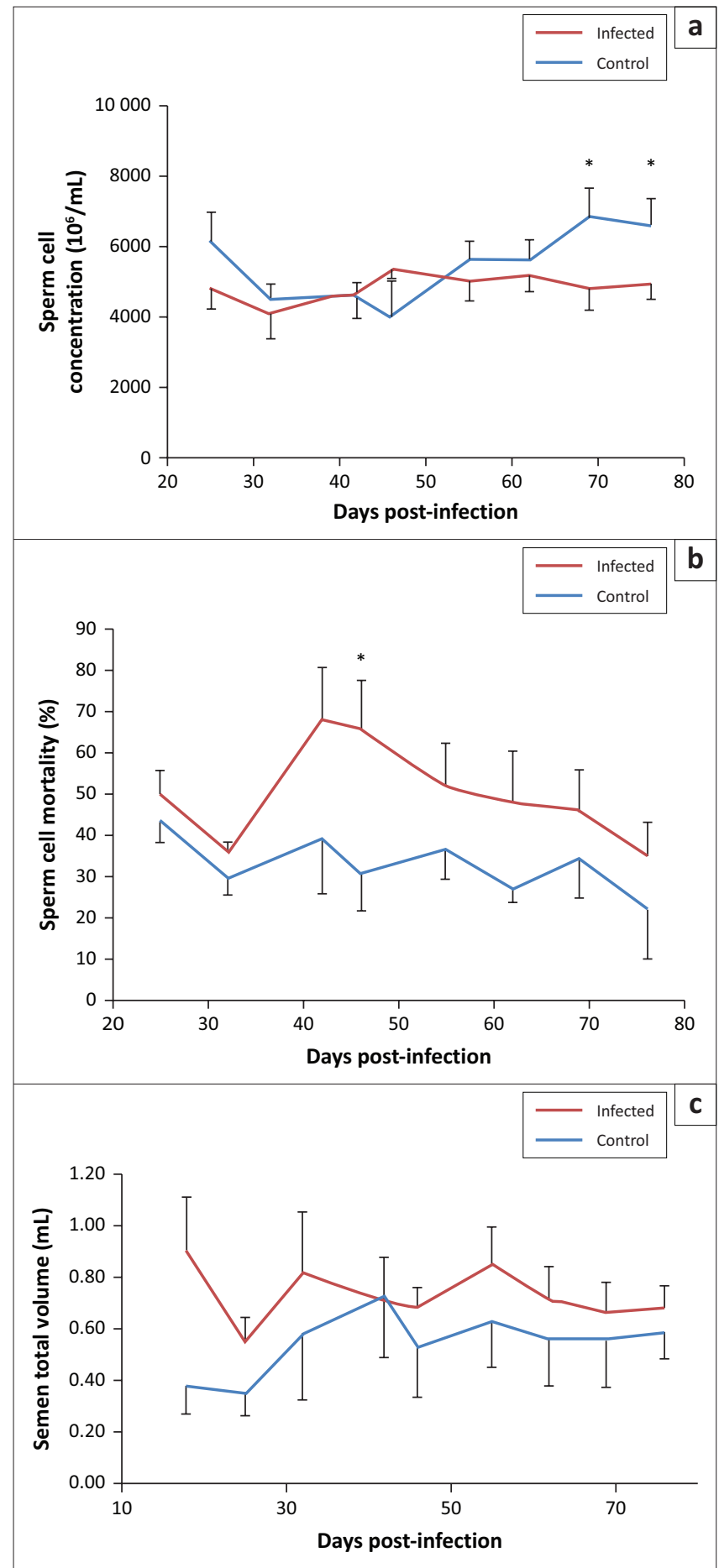

*, Differences between control and infected rams are significant at $p<0.05$.

FIGURE 3: Variation of (a) sperm cell concentration, (b) sperm mortality rate and (e) ejaculate total volume in Haemonchus contortus infected and control rams.

Sperm mortality rate was significantly higher in infected animals $(p<0.05)$ at day 46 post-infection when compared to the control (Figure $3 b$ ) and tended to remain higher until the end of the experiment without reaching statistical significance. There was only a significant effect of infection on ejaculate volume $(p=0.04)$, but this effect was not observed for time (Figure 3c). Average figures were $0.55 \mathrm{~mL} \pm 0.17 \mathrm{~mL}$ and $0.73 \mathrm{~mL} \pm 0.14 \mathrm{~mL}$ for control and infected groups, respectively.

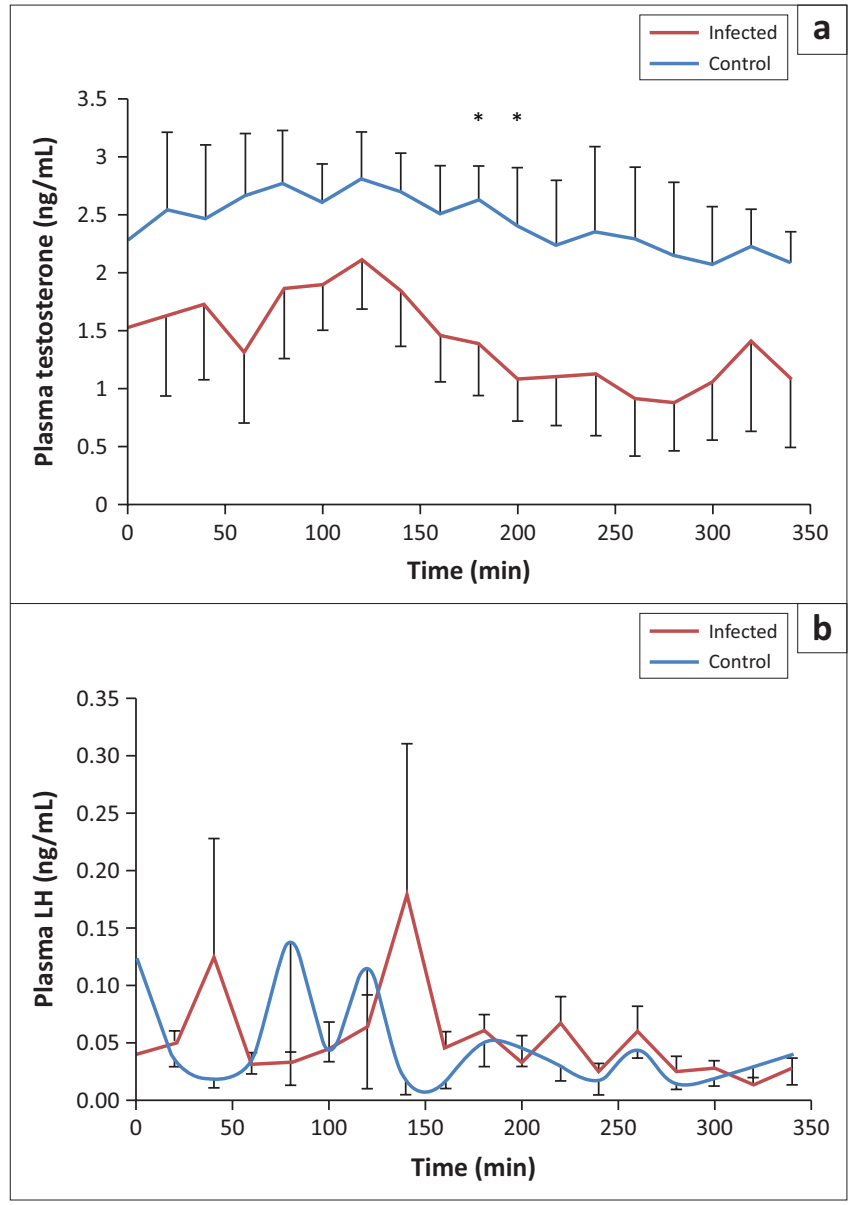

*, Differences between control and infected rams are significant at $p<0.05$.

FIGURE 4: Variation of (a) plasma testosterone and (b) plasma luteinising hormone concentrations in Haemonchus contortus infected and control rams.

\section{Hormone concentrations}

There was only a significant effect of infection on plasma testosterone concentrations $(p<0.001)$. Time and the interaction infection*time had no significant effect on plasma testosterone concentrations $(p>0.05)$. Overall the serial sampling period, mean concentrations of plasma testosterone concentrations were lower for infected than for control animals; significant differences were reached at the 10th and 11th sampling times. The same concentrations tended $(0.08<p<0.1)$ to be lower at the 9 th, 14 th and 15 th sampling times for infected versus control rams (Figure 4a). Testosterone pulse frequency tended $(p=0.06)$ to be lower in infected versus control rams $(1.01 \pm 0.12$ and $1.42 \pm 0.13$, respectively) (Figure 5). For the individual testosterone profiles, areas delineated by measured concentrations were calculated using the trapezoid rule (Figure 5), and average figures were $479.28 \mathrm{ng} / \mathrm{mL}(\mathrm{SEM}=97.79)$ and $831.44 \mathrm{ng} / \mathrm{mL}(\mathrm{SEM}=107.22)$ for infected and control rams, respectively $(p<0.001)$. No significant effect of infection, time and the interaction infection*time was observed in plasma LH levels during the whole sampling period $(p>0.05)$ (Figure $4 \mathrm{~b})$. For control animals, there was a positive correlation between testosterone and LH plasma levels ( $p<0.05)$; no such relationship was observed for infected animals. 


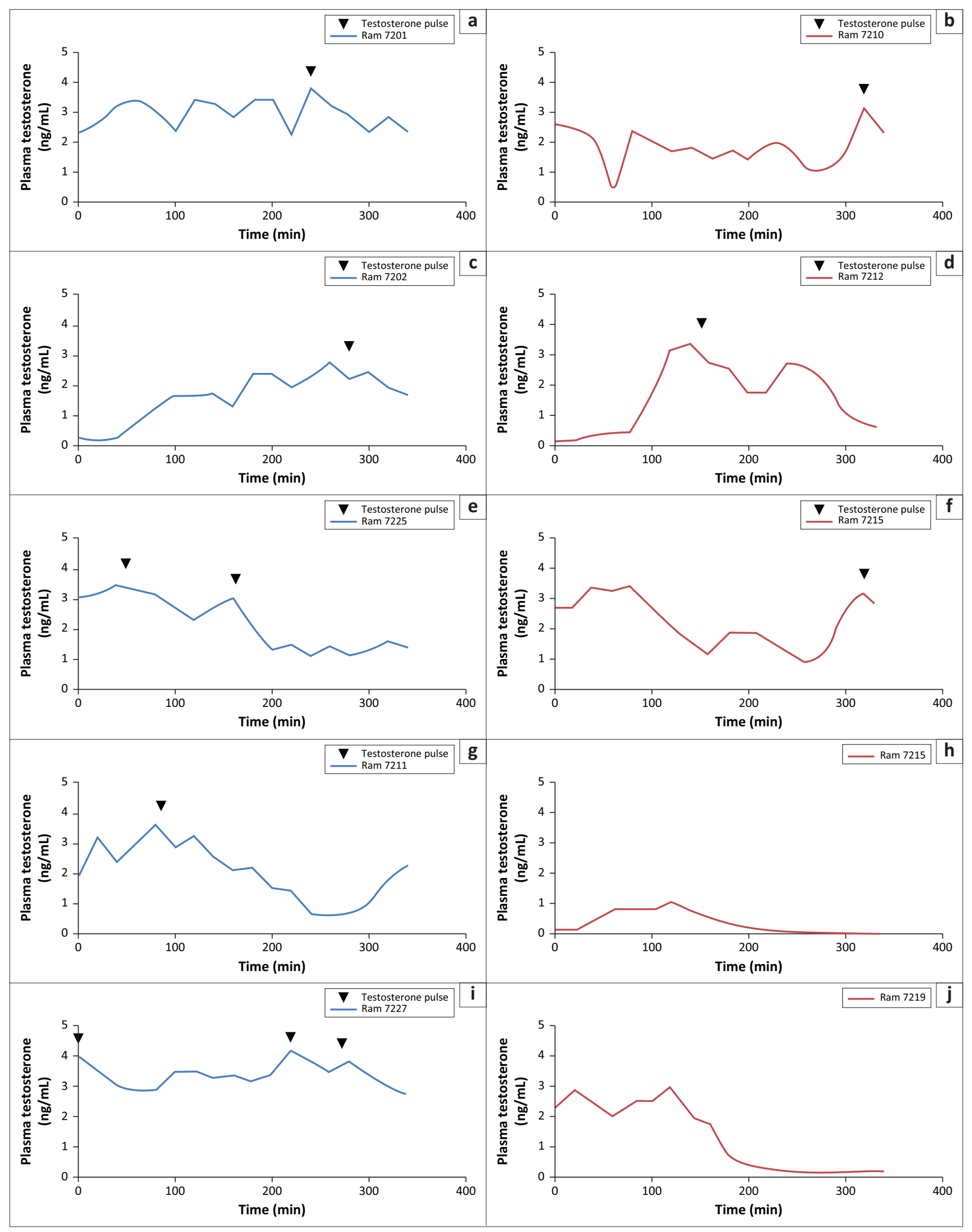

FIGURE 5: Plasma testosterone profiles in Haemonchus contortus. Control rams: (a) Ram 7201, (c) Ram 7202, (e) Ram 7225, (g) Ram 7211 , (i) Ram 7227 and infected rams: (b) Ram 7210, (d) Ram 7212, (f) Ram 7215, (h) Ram 7216, (j), Ram 7219. 


\section{Discussion}

Sheep are amongst the major economically important livestock species in Tunisia. Barbarine sheep is the most frequent breed representing $60 \%$ of the total sheep population in Tunisia, and it is also dominant in other North African countries such as Libya and Eastern Algeria (Ben Salem, Lassoued \& Rekik 2011; Majdoub-Mathlouthi et al. 2013). The Barbarine breed is facing several environmental stressors. The major constraint is feed availability from natural pasture, which is quantitatively limited and has a very poor quality (Majdoub-Mathlouthi et al. 2013). In addition to this, the breed is also highly exposed to several health issues (Gharbi et al. 2013; Rjeibi et al. 2014) involving viral, bacterial and parasitic diseases such as toxoplasmosis (Khayeche et al. 2014), mange (Ben Chakroun \& Jemli 1999), lungworms (Lahmar et al. 2013) and gastrointestinal parasites (Akkari et al. 2012). Gastrointestinal nematodes are amongst the most important pathogens of ruminants worldwide (Mahieu et al. 2009; Silva et al. 2015), and production losses caused by helminth species can be substantial (Albers et al. 1987; Beck, Moir \& Meppem 1985). Haemonchus contortus is the main hematophagous gastrointestinal helminth of sheep; its high host specificity was confirmed by Silva et al. (2015).

The infected group received $30000 \mathrm{H}$. contortus third-stage larvae orally, and at days 30 and 70 post-infection, the faecal egg counts in the six infected animals reached an average of $6200 \mathrm{eggs} / \mathrm{g} \pm 664.24 \mathrm{eggs} / \mathrm{g}$ and $5000 \mathrm{eggs} / \mathrm{g} \pm 886.00 \mathrm{eggs} / \mathrm{g}$, respectively. Under other conditions, investigators reached different levels of haemonchosis using experimental infection (Getachew et al. 2015; Machado et al. 2014).

Some authors compared cryopreserved and unfrozen L3 of H. contortus infection (Van Wyk 1999). A mean of 33.4\% of cryopreserved $H$. contortus L3 developed in sheep, compared with a percentage of 43.7 for unfrozen L3 of the same species.

Results from this study confirmed that infection had actually occurred since $H$. contortus infection is known to cause significant changes of haematological parameters mainly anaemia (Al-Quaisyet al. 1987). This is reflected by the significant decrease in haemoglobin, red blood cells count and haematocrit in response to $H$. contortus infection. It was also established that there is a gradual decline in haemoglobin concentration during the post-infection period (Bordoloi et al. 2012), red cell losses (Dargie \& Allonby 1975) and reduction of the haematocrit (Albers et al. 1990).

The main objective of this work was to test the effect of $H$. contortus infection on reproductive traits in adult rams. Although $H$. contortus infections are a well-known problem, to our knowledge there are few published studies dealing with the effect of $H$. contortus infection on semen characteristics in sheep. In our study, semen traits were depressed due to the infection. All changes took place towards the middle, up to the end of the experiment. These changes cannot be solely related to the animal's health status since infected animals did not show modification in clinical and body condition parameters after infection with $H$. contortus. In fact, live weight, heart rate, respiratory rate and rectal temperature averages did not show major differences between infected and control rams; this is one more indication of the adaptive capacity of the studied breed to cope with harsh environmental conditions and non-optimal husbandry conditions (Ben Salem et al. 2011). Our finding is not consistent with other reports. Indeed, Hayat et al. (1996) found that inhabiting the abomasum of sheep and goats, $H$. contortus cause blood loss resulting in reduced feed intake and decreased body weight. Recently, Tonin et al. (2014) reported that crossbred Corriedale lambs infected with 15000 third-stage larvae of $H$. contortus given as three divided doses were losing their physiological condition progressively; getting weak, lethargic, pale and experiencing depressed feed intake. Further, subclinical parasitism in dairy goats resulted in a reduction in body condition score when infected with 5000 third-stage larvae (Hoste \& Chartier 1993).

In this study, infected animals presented a decrease in plasma testosterone concentrations compared to control rams. Testosterone levels after 4 weeks of infection with 5000 infective larvae of $H$. contortus were shown to have a significant positive correlation with worm burden (Gauly et al. 2006). It was concluded in the same study that female lambs were more resistant to an experimental $H$. contortus infection when compared with male lambs, and testosterone seemed to play an important role in resistance. In our study, the modification in testosterone concentrations was not accompanied by a change in LH concentrations. This shows that the function of the hypothalamus-pituitary system was not affected by the infection. Changes in plasma testosterone concentrations may be due to a disruption taking place in the Leydig cells' function, hampering their response to LH stimulus. The lack of a correlation between LH and testosterone plasma levels in infected animals supports this statement. However, this working hypothesis requires further experimental evidence.

Nevertheless, other workers did not show an effect of parasite infection on reproductive performances of Santa Inês and Morada Nova ewes in Brazil. Females of these two breeds showed good reproductive performance, with no differences in conception rate, return to oestrus, multiple births and prolificacy (Issakowicz et al. 2016). A differentiated sex response to infection with Haemonchus may therefore be suspected between these results from Brazil and our findings.

\section{Conclusion}

Though preliminary, these results are important as far as the management of sheep reproduction with relation to parasite infection under conditions of insufficient health care is concerned. Significant changes were noticed between infected and control animals for reproductive parameters. The study could not determine whether Haemonchus-induced anaemia was the primary cause compromising male reproduction or whether infection directly affected sperm traits. It is also important from a management perspective to assess whether the recorded depression in reproductive traits has an impact on the actual mating capacity of the rams under field conditions. 


\section{Acknowledgements}

The study was financially supported by Laboratoire d'épidémiologie des infestations enzootiques des herbivores en Tunisie: application à la lutte (Ministère de l'enseignement supérieur et de la recherche scientifique, Tunisia). The authors thank Mr Jalel Khelil, Mr Limam Sassi, Mr Bechir Guesmi, Mr Mokhtar Dhibi and Mr Taoufik Lahmar for their support. The authors thank the department of biochemistry of the National School of Veterinary Medicine for biochemical analyses. This work was partly supported by ICARDA-led research program Consultative Group on International Agricultural Research Research Programme (CRP) dryland systems.

\section{Competing interests}

The authors declare that they have no financial or personal relationships which may have inappropriately influenced them in writing this article.

\section{Authors' contributions}

M.R. (Tunisia), M.G. and M.R. (Jordan) planned and conceived the experiments. M.R. (Tunisia), M.R. (Jordan), H.A. and N.L. provided biologic material. M.R. (Tunisia) collected samples. M.R. (Tunisia), M.R. (Jordan), M.G., I.B.S and M.R.R. performed all other laboratory work and analysed the data. M.R. (Tunisia), M.R. (Jordan), M.G. and M.R.R. interpreted the results and designed the figures. M.R. (Tunisia), M.R. (Jordan) and M.G. wrote the manuscript. All authors read and approved the final manuscript.

\section{References}

Akkari, H., Gharbi, M. \& Darghouth, M.A., 2011, 'Infestation of tracer lambs by Fasciola hepatica in Tunisia: Determining periods for strategic anthelmintic treatments', Revue scientifique et technique de I'OIE 30(3), 917-929. http:// dx.doi.org/10.20506/rst.30.3.2084

Akkari, H., Gharbi, M. \& Darghouth, M.A., 2012, 'Dynamics of infestation of tracers lambs by gastrointestinal helminths under a traditional management system in the North of Tunisia', Parasite 19(4), 407-415. http://dx.doi.org/10.1051/ parasite/2012194407

Albers, G.A., Gray, G.D., Jambre, L.F., Barger, I.A. \& Barker, J.S.F., 1990, 'The effect of Haemonchus contortus infection on haematological parameters in young Merino sheep and its significance for productivity', Animal Science 50(1), 99-109.

Albers, G.A., Gray, G.D., Piper, L.R., Barker, J.S., Le Jambre, L.F. \& Barger, I.A., 1987 'The genetics of resistance and resilience to Haemonchus contortus infection in young merino sheep', International Journal of Parasitology 17(7), 1355-1363. http://dx.doi.org/10.1016/0020-7519(87)90103-2

Al-Quaisy, H.H., Al-Zubaidy, A.J., Altaif, K.I. \& Makkawi, T.A., 1987, 'The pathogenicity of haemonchosis in sheep and goats in Iraq. Clinical, parasitological and haematological findings', Veterinary Parasitology 24, 221-228.

Baril, G., Chemineau, P., Cognie, Y., Guérin, Y. \& Leboeuf, B., 1993, Manuel de formation pour l'insémination artificielle chez les ovins et les caprins [Training manual for artificial insemination in sheep and goats], Food \& Agriculture manual for artificia
Organization, Rome.

Beck, A., Moir, B. \& Meppem, T., 1985, 'The cost of parasites to the Australian sheep industry', Quarterly Review Rural Economy 7, 336-343.

Ben Chakroun, N. \& Jemli, M., 1999, 'Essai de la doramectine dans le traitement de la gale psoroptique et des strongyloses digestives et pulmonaires du mouton en Tunisie [Testing of doramectin in the treatment of mange and digestive and pulmonary strongyles of sheep in Tunisia]', Revue de Médecine Vétérinaire 10, 819-826.

Ben Salem, H., Lassoued, N. \& Rekik, M., 2011, 'Merits of the fat-tailed Barbarine sheep raised in different production systems in Tunisia: Digestive, productive and reproductive characteristics', Tropical Animal Health and Production 43(7) 1357-1370. http://dx.doi.org/10.1007/s11250-011-9863-8

Blood, D.C. \& Radostits, O.M., 1989, Veterinary medicine, Baillière Tindall, London.

Bordoloi, G., Jas, R. \& Ghosh, J.D., 2012, 'Changes in the haemato-biochemical pattern due to experimentally induced haemonchosis in Sahabadi sheep', Journal of Parasitic Diseases 36, 101-105. http://dx.doi.org/10.1007/s12639-011-0079-7
Bussiéras, J. \& Chermette, R., 1995. Abrégé de Parasitologie vétérinaire. Helminthologie, Service de Parasitologie, Ecole Nationale Vétérinaire d’Alfort, Paris.

Dargie, J.D. \& Allonby, E.W., 1975, 'Pathophysiology of single and challenge infection of Haemonchus contortus in Merino sheep: Studies on red cell kinetics and the "self-cure" phenomenon', International Journal of Parasitology 5(2), 147-157. http://dx.doi.org/10.1016/0020-7519(75)90021-1

Dickson, K.A. \& Sanford, L.M., 2005. 'Breed diversity in FSH, LH and testosterone regulation of testicular and in libido of young adult rams on the southeastern Canadian prairies', Small Ruminant Research 56 (1-3), 189-203. http://dx.doi. org/10.1016/j.smallrumres.2004.06.002

Diekman, M.A., Green, M.L., Fears, T.E., Malayer, J.R. \& Kuczek, T., 1991, 'Effect of sampling interval on serum concentrations of LH, FSH and PRL in prepubertal, ovariectomized gilts', Biology of Reproduction 45(5), 755-763. http://dx.doi. org/10.1095/biolreprod45.5.755

Euzéby, J., 1981, Diagnostic expérimental des helminthoses animales. Travaux pratiques d'helminthologie vétérinaire. Tome l: généralités, diagnostic ante mortem, Informations Techniques des Services Vétérinaires, Paris, $340 \mathrm{p}$.

Gauly, M., Schackert, M., Hoffmann, B. \& Erhardt, G., 2006, 'Influence of sex on the resistance of sheep lambs to an experimental Haemonchus contortus infection', Deutsche Tierärztliche Wochenschrift 113(5), 178-181.

Getachew, T., Alemu, B., Sölkner, J., Gizaw, S., Haile, A., Gosheme, S., et al., 2015, 'Relative resistance of Menz and Washera sheep breeds to artificial infection with Haemonchus contortus in the highlands of Ethiopia', Tropical Animal Health Production 47(5), 961-968. http://dx.doi.org/10.1007/s11250-015-0815-6

Gharbi, M., Zribi, L., Jedidi, M., Chakkhari, H., Hamdi, S., R'hayem, S., et al., 2013 'Prevalence of Toxoplasma gondii infection in Tunisian sheep', Bulletin de la Société de Pathologie Exotique 106, 184-187. http://dx.doi.org/10.1007/s13149013-0290-4

Gonzalez-Bulnes, A., Meza-Herrera, C.A., Rekik, M., Ben Salem, H. \& Kridli, R.T., 2010 'Limiting factors and strategies for improving reproductive outputs of small ruminants reared in semi-arid environments', in M. Kara (ed.), Semi-arid environments: Agriculture, water supply, pp. 41-62, Nova Science Publishers Inc. Hauppauge, NY.

Hayat, C.S., Hussain, S.M., Iqbal, Z., Hayat, B. \& Akhtar, M., 1996, 'Effect of parasitic nematodes on haematology and productivity of sheep', Pakistanis Veterinary Journal 16, 81-83.

Hoste, H. \& Chartier, C., 1993, 'Comparison of the effects on milk production of concurrent infection with Haemonchus contortus and Trichostrongylus
colubriformis in high- and low-producing dairy goats', American Journal of colubriformis in high- and low-produ
Veterinary Research 54, 1886-1893.

Issakowicz, J., Sampaio-Issakowicz, C.K., Bueno, M.S., Dias da Costa, R.L., Katiki, L.M., Geraldo, A.T., et al., 2016, 'Parasitic infection, reproductive and productive performance from Santa Inếs and Morada Nova ewes', Small Ruminant Research performance from Santa Inês and Morada Nova ewes', Small Rumin

Khayeche, M., Mhadhbi, M., Gharbi, M., Nasfi, I. \& Darghouth, M.A., 2014, 'Detection of Toxoplasma gondii infection of sheep slaughtered in the governorate of Sousse on the occasion of the Muslim sacrifice feast (Eid Al-Adha) and analysis of risk factors', Bulletin de la Société de Pathologie Exotique 107, 60-63. http://dx.doi. org/10.1007/s13149-014-0325-6

Lahmar, S., Trifi, M., Naceur, S.B., Bouchhima, T., Lahouar, N., Lamouchi, I., et al., 2013 , 'Cystic echinococcosis in slaughtered domestic ruminants from Tunisia', Journal of Helminthology 87(3), 318-325. http://dx.doi.org/10.1017/S0022149X12000430

Machado, V., Da Silva, A.S., Schafer, A.S., Aires, A.R., Tonin, A.A., Oliveira, C.B., et al., 2014, 'Relationship between oxidative stress and pathological findings in abomasum of infected lambs by Haemonchus contortus', Pathology Research and Practice 210(12), 812-817. http://dx.doi.org/10.1016/j.prp.2014.09.006

Mahieu, M., Arquet, R., Fleury, J., Coppry, O., Marrie-Magdeleine, C., Boval, M., et al., 2009. 'Contrôle intégré du parasitisme gastro-intestinal des petits ruminants au pâturage en zone tropicale humide', Proceedings Rencontres Recherche Ruminants 16, 265-268.

Majdoub-Mathlouthi, L., Saïd, B., Say, A. \& Kraiem, K., 2013, 'Effect of concentrate level and slaughter body weight on growth performances, carcass traits and meat
quality of Barbarine lambs fed oat hay based diet', Meat Science 93(3), 557-563. quality of Barbarine lambs fed oat hay based diet',
http://dx.doi.org/10.1016/j.meatsci.2012.10.012

Raynaud, J.P., 1970,'Etude de l'efficacité d'une technique de coproscopie quantitative pour le diagnostic de routine et le contrôle des infestations parasitaires des bovins, ovins, équins et porcins [Study of an egg-count technique for diagnosis and control of parasitic infestation in cattle, sheep, goats, pigs, and horses]',Annales de Parasitologie Humaine et Comparée 45, 321-342.

Rjeibi, M.R., Gharbi, M., Mhadhbi, M., Mabrouk, W., Ayari, B., Nasfi, I., et al., 2014, 'Prevalence of piroplasms in small ruminants in North-WestTunisia and the first genetic characterisation of Babesia ovis in Africa', Parasite 21, 23. http://dx.doi. genetic characterisation of Babesi
org/10.1051/parasite/2014025

Russell, W.M.S. \& Burch, R.L., 1959, The principles of humane experimental technique, Methuen, London.

Silva, M.R.L., Amarante, M.R.V., Bresciani, K.D.S. \& Amarante, A.F.T., 2015, 'Hostspecificity and morphometrics of female Haemonchus contortus, H. placei and $H$. similis (Nematoda: Trichostrongylidae) in cattle and sheep from shared pasture in São Paulo State, Brazil', Journal of Helminthology 89(3), 302-306. http://dx.doi. org/10.1017/S0022149X14000078

Tonin, A.A., Da Silva, A.S., Schafer, A.S., Aires, A.R., Oliveira, C.B., Zanini, D., et al., 2014, 'Influence of experimental infection by Haemonchus contortus on acetyl cholinesterase activity in lymphocytes of lambs', Experimental Parasitology 139 19-23. http://dx.doi.org/10.1016/j.exppara.2014.02.006

Van Wyk, J.A., 1999, 'A comparison of the infectivity of cryopreserved versus unfrozen infective larvae of Haemonchus contortus, Trichostrongylus colubriformis and
Trichostrongylus axei', Onderstepoort Journal of Veterinary Research 66, 285-289. Trichostrongylus axei', Onderstepoort Journal of Vet
http://dx.doi.org/10.1016/j.exppara.2014.02.006 